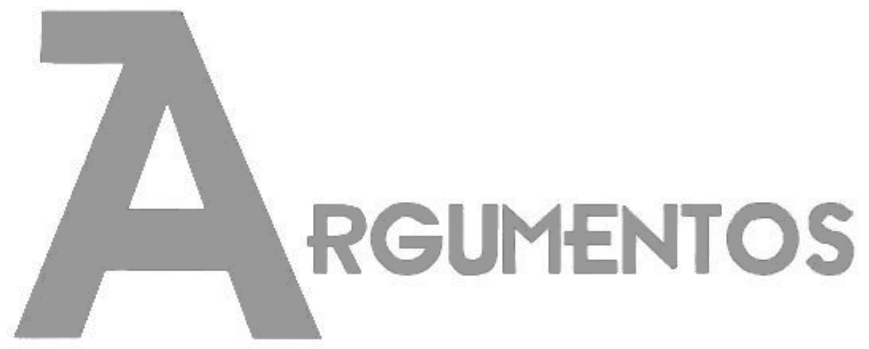

Vol. 16, n. 1, jan./jun. 2019 ISSN: 2527-2551 (online)

http://www.periodicos.unimontes.br/argumentos

\title{
Resenha - Dilemas éticos e morais no discurso tecnocientífico do aconselhamento genético
}

PAULA, Bruno Lucas Saliba de. Híbridos e mutantes: estudo comparativo entre aconselhamento genético e eugenia. Montes Claros: Editora Unimontes, 2018.

André Pereira ${ }^{1}$

Recebido em: 24/04/2019

Aprovado em: 22/06/2019

O debate sociológico em torno da eugenia, suas implicações e consequências é um tema polêmico, pois revela valores morais firmemente arraigados e díspares na sociedade. Posicionamentos favoráveis e contrários fazem uso de instrumentos tecnocientíficos para embasar suas argumentações, e assim defender quais características físicas são consideradas positivas, quais são negativas, quais vidas merecem servividas, entre outros posicionamentos. Longe de encerrar este debate com um posicionamento final, Híbridos e mutantes enriquece o entendimento deste tema ao trazer para a discussão o aconselhamento genético e tecer comparações com as práticas eugenistas.

Bruno Saliba toma cuidado para não afirmar categoricamente que 0 aconselhamento genético é a eugenia do século XXI, mas sim que existem elementos fundantes da argumentação a favor da eugenia que são encontradas no discurso do

\footnotetext{
1 Doutor em Sociologia pela Universidade Federal de Minas Gerais - Belo Horizonte, Brasil. E-mail:< andreu.pereira@gmail.com >. ORCID: https://orcid.org/0000-0003-3795-9189.
} 
aconselhamento genético. As distinções que existem em ambos os discursos remetem a duas formas distintas de controle e governamentalidade: o poder disciplinar e a biopolítica:

A disciplinarização do corpo individual e a biopolítica da população constituem (...) dois modos de exercício de poder sobre a vida, ambos caracterizados por uma manipulação científica da vida mesma a partir de seus mecanismos internos - doenças, mutações, evoluções, reproduções, mortes, etc. (PAULA, 2018, p. 26)

A teoria de Michel Foucault aparece de maneira natural na explicação das similaridades e distâncias entre a eugenia e o aconselhamento genético. Enquanto o poder disciplinar foca um controle do Estado sobre a vida dos cidadãos da nação, a biopolítica se entranha na subjetividade de cada indivíduo, buscando individualizar as ações de controle e tornar o indivíduo responsável pelo seu próprio desempenho na sociedade. A lei da vacinação obrigatória - e a revolta subsequente - são exemplos levantados para apresentar, de maneira didática, de que maneira o argumento tecnocientífico é empregado pelo Estado como forma de submeter a população a um controle sobre suas próprias vidas e seus próprios corpos.

A biopolítica, por outro lado, não busca impor uma ação estatal sobre a saúde, mas sim desenvolver uma "obrigação moral" (Ibidem, p. 90) sobre a subjetividade dos indivíduos, ao fazer uso de conhecimentos tecnocientíficos para "provar" para a população qual é o modo correto de viver a vida. A ideia de correto é aqui empregada em sentido econômico, onde "a qualidade do aparato biológico ou da saúde de uma população é medida em termos econômicos, de riscos, fluxos, custos e benefícios" (Ibid, p. 89).

A biopolítica está ligada intimamente a um modo liberal de calcular a vida, com mensurações estatísticas, cálculos racionais e benefícios comparáveis entre diferentes cursos de ações. A vida passa a ser observada de perto pela governamentalidade, que calcula objetivamente como melhor se deve viver. A racionalização em custos e benefícios possui um caráter duplo: é tanto um cálculo do que rende mais ou dispende mais para a população quanto uma política econômica do Estado. Ao se eximir de uma aproximação mais direta e incisiva sobre o controle dos corpos (como em um Estado que faz uso predominantemente do poder disciplinar), o Estado evita gastos com 
políticas públicas, ao mesmo tempo em que possui uma população mais saudável e produtiva.

Esta cisão entre os modos de governamentalidade não são excludentes; muitas vezes, é possível encontrar elementos de predominância de um modo, mas também ser observado certos aspectos do outro. Quando existem conflitos entre os "indivíduos livres e investidores de si mesmos" (Ibid, p. 124) e o discurso legítimo, quando os sujeitos têm interesses que entram em conflito com o que é afirmado enquanto o curso correto de ação a se tomar, é possível observar uma maior dimensão do poder disciplinar (ou seja, da imposição da norma correta). A biopolítica continua sendo, no entanto, a governamentalidade predominante, que busca o convencimento da população através de um discurso científico legítimo.

O aconselhamente genético pode ser percebido como uma forma do exercício da biopolítica, pois não é uma política de governo imposta sobre a população, mas a inculcação de um cuidado de si. Em vez de uma prática de controle geral sobre todos os indivíduos, é uma forma de controle descentralizada, atuando sobre cada sujeito particular, e cada um é responsável por seu bem-estar. Em vez de obrigar os sujeitos a irem ao médico, constrói-se na própria subjetividade dos indivíduos uma necessidade de cuidar, controlar, fiscalizar e regular seu corpo, de acordo com os conhecimentos tecnocientíficos presentes no discurso vigente.

Paula explica a dupla importância discursiva na análise do aconselhamento genético. Abordemos a primeira dimensão desta leitura, que é o dis curso de veridicção. Este discurso é a legitimação de uma estratégia política específica, tomando esta como a única verdade possível:

...as informações cientificamente obtidas são tidas como objetivas e
verdadeiras, e a partir delas que se toma decisões (...), e não com base em
tradições, valores ou ideologias (Ibid, p. 20)

Foucault aponta que a ciência se mune de instrumentos técnicos (estatísticas, probabilidades, base de dados, projeções e simulações) para afirmar que suas proposições não são opiniões, com base em valores, mas dados concretos da realidade - inegáveis, e, portanto, irrefutáveis. 
Ao produzir um norte sobre o que é certo e o que é errado, a ciência dá as bases para que o aconselhamento genético se apresente não enquanto uma escolha supérflua, e sim como um dever de cada indivíduo de tomar as melhores escolhas para si, em nível orgânico: qual parceiro/a é ideal para a reprodução, quais são as possíveis condições que aparecem em um dado casal, como evitar uma condição ou aumentar as chances de outra condição.

A segunda dimensão da análise da questão discursiva se encontra quando Paula aponta como a medicina deixa de se orientar com base em um linguajar da biologia e da química, e passa a empregar "um vocabulário oriundo da linguística, da teoria da comunicação e da computação" (Ibid, p. 57). Este léxico consegue produzir um efeito na sociedade de maneira a explicar as variações bioquímicas enquanto "um problema de codificação" (Ibid, p.58, grifo no original). Desta maneira, é possível explicar as modificações e variações possíveis de serem produzidas através do aconselhamento genético não como uma alteração das características naturais da vida (como na eugenia), e sim tratando "a doença (...) como um 'defeito' de código" (Ibid, p. 58, grifo próprio). Desta maneira, retira-se o caráter subjetivo e moral da escolha pessoal do que é melhor ou pior, e trata-se enquanto uma correção da informação genética dos sujeitos.

Não se furtando de levar o debate para as demais áreas, o autor também usa de uma série de análises de diferentes áreas para explicar seu objeto. Embora não haja problema em realizar uma análise estritamente sociológica, Paula adentra em outras áreas do conhecimento para solidificar suas bases analíticas, combinando desde a epistemologia feminista de Donna Haraway até leituras médicas sobre o aconselhamento genético. Desta maneira, o resultado final da pesquisa pode ser de interesse de diversas áreas, pelo amplo espectro teórico e analítico desenvolvido.

A crítica ao uso da ciência é notadamente central no livro de Paula, que busca explicitar o caráter não apenas parcial que a ciência tem na sociedade, mas também sua tentativa de esconder essa sua parcialidade. Enquanto a eugenia era apresentada a partir de posições claramente subjetivas (qual é a melhor raça, quais são as melhores características), o aconselhamento genético faz uso de dados, apresentados enquanto objetivos e neutros, em uma explicação tecnocientífica do que é melhor para os sujeitos. Não é a opinião do médico que está sendo apresentada, mas sim todo um discurso 
médico que afirma o que é melhor para a população, olhando para cada indivíduo particular, em suas características mais íntimas (seu código genético).

O debate teórico não acaba apenas na descrição do objeto, mas se aprofunda radicalmente quando Paula nos traz um elemento central da teoria foucaultiana, e como este se apresenta em seu objeto. Estamos aqui nos referindo ao elemento da liberdade, que Foucault aponta como indispensável no exercício da biopolítica. Os indivíduos são levados, a partir de um argumento tecnocientífico convincente, a concordar com o discurso de veridicção vigente, aquele que determina qual é o discurso que será tomado como correto. Argumentar contra o aconselhamento genético, com base em valores morais, não consegue produzir o efeito desejado, pois a lógica quantitativista explica, "por $a+b$ ", por que esta posição é a melhor a se tomar. No entanto, a liberdade que Foucault sugere permite que os sujeitos se contraponham a este discurso, mas não trazendo um discurso externo, e sim dominando os códigos do discurso de veridicção, e contra-argumentando dentro de seu próprio exercício de poder. Ou seja, usar o próprio discurso de poder contra o próprio discurso.

Este uso da liberdade para contestar o discurso de veridicção nos é apresentado por Paula com o exemplo do casal de surdas que fez uso do aconselhamento genético para realizar uma gravidez na qual o embrião selecionado tivesse o gene da surdez. Fazendo uso de argumentos legais (são clientes da empresa privada que realiza o aconselhamento, portanto têm direito de escolher o embrião que quiserem) e sociais (não consideram surdez uma deficiência, e sim uma cultura; logo, uma criança com surdez não é deficiente, é distinta), o casal articulou o discurso a favor de um aconselhamento genético de uma maneira imprevista pela própria lógica do discurso. No entanto, por articularem corretamente o discurso médico, souberam defender sua posição e usar o discurso de veridicção a seu favor.

Ao trazer este exemplo, Paula consegue realizar dois feitos notáveis. O primeiro, exemplificar a teoria foucaultiana com um caso concreto, no qual é possível entender sua teoria sem se perder em recursos linguisticos, e como pode ser empregada para entender determinados fenômenos sociais. Ao explicar a eugenia, o autor vincula imediatamente esta prática a uma governamentalidade disciplinar; e, ao distinguir a eugenia do aconselhamento genético, realiza com clareza suficiente a distinção entre o poder disciplinar e a biopolítica. É possível ter uma compreensão clara dos conceitos 
teóricos desenvolvidos por Foucault ao associá-los ao debate genético aqui desenvolvido.

Dito isto, importante apontar que certas análises da obra de Foucault, por sua complexidade, permitem diversas interpretações. Uma delas é quando Paula afirma que o conceito de biopolítica permite "ultrapassar dicotomias consolidadas, como a oposição ideológica esquerda versus direita" (Ibid, p. 44). Embora Foucault seja crítico das dicotomias tradicionais do pensamento acadêmico de sua época, tampouco desfaz uma leitura classista da sociedade.

Para ele, a ideia de direita e esquerda existe enquanto uma complexidade de direitas e esquerdas, pois desnaturaliza-se a identidade ideológica a partir de uma posição única, determinada pelo confronto no domínio dos meios de produção. Não há predeterminação de uma classe social que detenha a posição de esquerda ou de direita, mas posições que se assumem enquanto esquerda ou direita. Portanto, embora haja uma crítica às dicotomias acadêmicas (predominantemente marxistas) de sua época, não há uma negação destas, mas um aprofundamento na complexidade de suas manifestações.

É também necessário notar que há uma leitura problemática do conceito de neoliberalismo: "os neoliberais acreditam que mercado e concorrência não existem por si só, mas carecem de ser criados por políticas governamentais" (p. 45). Foucault afirma diferentemente, quando indica que, em um governo neoliberal, existe uma “autolimitação da razão governamental" (FOUCAULT, 2008, p. 28). A função do Estado, em relação ao mercado, é de

deixá-lo agir com o mínimo possível de intervenções, justamente para que ele possa formular a sua verdade e propô-la como regra e norma à prática governamental. Esse lugar de verdade não é, evidentemente, a cabeça dos economistas, mas o mercado (Ibid, p. 42).

Desta maneira, o neoliberalismo seria o inverso: o fim de qualquer política governamental, dado que toda tentativa de agir sobre a população enquanto um todo entra em conflito com as particularidades individuais, o que cada sujeito acha melhor para si e o melhor caminho para alcançar seus resultados. Em vez de políticas de governo, "o indivíduo, por vontade própria, se integra num sistema de cooperação" (MISES, 1990, p. 256), exercendo sua liberdade, enquanto "o mercado o orienta e lhe 
indica a melhor maneira de promover o seu próprio bem-estar, bem como o das demais pessoas (Ibid).

O segundo feito é realizado ao tirar o leitor de seu espaço de conforto, e quase que forçá-lo a se posicionar, trazendo um exemplo problemático, que o leitor pode tanto defender quanto criticar, e desta maneira entender a complexidade do problema. Paula não nos traz verdades absolutas ou encerra o debate acerca do aconselhamento genético, mas sim explica um fenômeno social acercando-o ao leitor, obrigando-o a se posicionar, a participar do debate.

\section{Bibliografia}

PAULA, Bruno Lucas Saliba de. Híbridos e mutantes: estudo comparativo entre aconselhamento genético e eugenia. Montes Claros: Editora Unimontes, 2018.

FOUCAULT, Michel. O nascimento da biopolítica. São Paulo: Martins Fontes, 2008.

MISES, Ludwig Von. Ação humana: um tratado de economia. Rio de Janeiro: Instituto Liberal, 1990. 